\title{
Understanding of Hadiths based on the Concept of Wasatiyyah al-Qaradhawi to Deal with Understanding of Extremism
}

\author{
Muhammad ARIF YAHYA \\ Muhammad RAZAK IDRIS \\ Research Centre for Theology and Philosophy \\ Faculty of Islamic Studies \\ Universiti Kebangsaan Malaysia \\ Bangi
}

AMRAN Abdul Halim

Muhammad IKRAM bin Abu Hassan

Faculty of Quranic and Sunnah Studies, Islamic Science

Universiti Of Malaysia

Nilai, Malaysia.

\author{
Mohamad ZULKIFLI Abdul Ghani \\ Research Centre for Dakwah and Leadership \\ Faculty of Islamic Studies \\ Universiti Kebangsaan Malaysia \\ Bangi
}

\begin{abstract}
This study aims to examine the method of al-wasatiyyah by al-Qaradhawi in understanding the hadith especially in relation to the Faith (aqidah) and Worship (ibadah), to curb the extreme understanding of hadiths. The present study follows a qualitative methodology by focusing on al-Qaradhawi's works In the filed of hadith which specifically study the concept of al-Wasatiyyah in the understanding of hadith.This study concludes that the concept of al-wasatiyyah introduced by al-Qaradhawi also presents an approach in understanding the hadiths of Rasulullah (pbuh). The approach put forward by al-Qaradawi is also in line with the hadith scholars' approach related to Figh al-Hadith. The study also concludes that the understanding of the hadith in the wrong approach can lead to extremism. This study has shown that the al-wasatiyyah concept introduced by al-Qaradawi is an important foundation in curbing extremism, especially the misunderstanding of the proponents of Islamic law such as the Quran and Hadith in modern times.
\end{abstract}

Keywords: al-wasatiyyah, al-Qaradawi, Hadith Understanding, Extremism

\section{Introduction}

Yusuf al-Qaradawi is famous for his concept of al-wasatiyyah in issuing the fatwas or in writing his religious works. He defines this trend or course as tayyar al-wasatiyyah al-islamiyyah. He further adds that the al-wasatiyyah approach is the fundamental characteristic of the Islamic religion itself. Therefore, the hadith, which is the secondary source of the Islamic religious law, also contains the same teachings about the concept of al-wasatiyyah. The hadiths quoted by al-Qaradawi emphasize on the description of the concept of al-wasatiyyah. This article discusses al-Qaradawi's approach and views of al-wasatiyyah, whose debate is based on the description of the hadiths by focusing on two topics which are the Islamic religious faith (aqidah) and the acts of worship (ibadah). The discussion of each of the above topics will be made together with the hadiths quoted by al-Qaradawi where the content of his discussion will be linked to this concept ofal-wasatiyyah. Before debating further on the hadiths, the author would present a few discussions on the methods and views of al-wasatiyyah according to al-Qaradawi, his works in the field of hadith, as well as presenting the basic principles in interacting with the hadiths as stated by al-Qaradawi.

\section{Al-Qaradawi: The Method and Approach of al-Wasatiyyah}

The method and approach of al-Qaradawiin expressing his views and in issuing the fatwas are based on the concept of al-wasatiyyah. As a great religious scholar who has personally witnessed and experienced various issues which have 
befallen the Muslim community, al-Qaradawi is extremely cautious in issuing the fatwas, particularly regarding the current issues. He has his own methods, just as the previous scholars would have had their own methods in issuing their fatwas. The current fatwa method used or applied by al-Qaradawi is to always be committed to the spirit of moderation between the group that is too strict or excessive (ifrat) and the one that is too loose or negligent (tafrit) ${ }^{1}$ According to Muhammad Kamil Ab Majid, this method and approach are also being practice by al-Qaradawi in his writings and missionary work. ${ }^{2} \mathrm{Al}-\mathrm{Q}$ aradawi introduces this stream of thinking as the moderate stream of Islam or tayar alwasatiyyah al-Islamiyyah, which is the stream that represents most of the roots of present day Islamic resurgence. ${ }^{3}$ According to Basri Ibrahim, the method of al-Qaradawi's al-wasatiyyah is also demonstrated through his stand among the groups who seek to separate themselves from Islamic laws based on the allegation that they are the followers of the current developments or trends, from the groups who try to retain the fatwas or views in their old (conventional) forms because they have too much regards for the views and uphold them too highly. ${ }^{4}$

Al-Qaradawi'sal-wasatiyyah method can also be proven through his simplified approach as compared to the more troublesome and inconvenient approach for the society with reference to the issue being discussed. However, the simplified approach is taken only for the branch or subsidiary subject matters (furu'). On the contrary, al-Qaradawi is firm with the main subject matters ( $u s u l$ ) related to the Islamic law. Yet, the simple approach of al-Qaradawi's views does not indicate that he distorts all the evidence or arguments (nas) of the Islamic law to achieve the simplified meaning of the law. Subject matters which involve nas that are muhkam (Quranic verses that have only one meaning, or those with a clear meaning, or are closed to any interpretations) or nas that are qat $i$ (definitive)in nature are not taken lightly by al-Qaradawi. The examples of such issues are the prohibition of usury in conventional banks, as well as the issue of smoking in the Muslim community since the methods of Islamic law have clearly rejected and denied them. He would only resort to the simpler approach in issues where no nas has been found to give a clear and explicit prohibition of the matter. An example of this situation is regarding the issue of the use of the triple talaq in a divorce (a form of divorce where the husband repudiates the marriage by uttering 'talaq' three times in a row). Al-Qaradawi is more inclined towards the views of Ibn Taymiyyah and Ibn Qayyim who believeonly one talaqis counted in the event of a triple talaq. In general, in the event of two opinions or views regarding an issue, that is between the more cautious view and a simpler or easier view, al-Qaradawi would choose the latter. According to BasriHashim, this approach is undertaken by al-Qaradawi in following the footsteps of the Prophet Muhammad PBUH who was never given an option unless he chose the simpler one, ifit was not sinful. ${ }^{5}$

\section{The Writings on the Hadith by al-Qaradawi}

Yusuf al-Qaradawi 's writing on hadith, which directly debate on the Prophetic traditions (sunnah) and the study of hadiths do not exceed ten works. His writings in this field fall in the category of the elaboration of the hadiths, while some would debate about the threats of the enemies of Islam towards the Prophetic traditions or about the anti-hadith groups. Other works are related to the current issues which involve the efforts in enhancing the study of hadiths. The following are the works of Yusuf al-Qaradawi on the hadiths, and their brief introduction before proceeding to the discussion of the hadiths that have been elaborated by Yusuf al-Qaradawi regarding his al-wasatiyyah method and approach.

\section{1) The Book of Fi Rihab al-Sunnah:SyarhAhadith al-Nabawiyyah}

The hadiths contained in this writing are a collection of hadiths related to the month of Ramadhan as well as its benefits, apart from the elaboration on the benefits of the alms or religious tax (zakat al-fitrah) that is made compulsory during the month of Ramadhan, and the privileges of the Laylatul Qadar with the detailed description of these hadiths.

\footnotetext{
${ }^{1}$ Basri Ibrahim, Metode Fatwa al-QaradawiDalamMenanganiIsu-IsuSemasa (Fatwa Method of Al-Qaradawi In Addressing Current Issues), al-Hidayah Publication: Batu Caves, Selangor, Malaysia, 2011.

${ }^{2}$ Muhammad Kamil Ab Majid, PemikiranKerohanian Yusuf al-Qaradawi : AnalisisSiri Bukunya al-Tariq Ila Allah (Spiritual Thoughts of Yusuf al-Qaradawi: Analysis of the Book Series of the al-Tariq Ila Allah),Thesis PhD, Department of Aqidah and Islamic Thought, Academy of Islamic Studies, Universityof Malaya, Malaysia, 2011.

${ }^{3}$ Al-Qaradawi, al-Sahwah al-IslamiyyahBayna al-Ikhtilaf al-Masyru' wa al-Tafarruq al-Madhmum(Islamic Awakening Between Legitimate Difference andDistortion), cet. ke 5, Dar al-Sahwah, Cairo, 1994.

${ }^{4}$ Basri Ibrahim, Metode Fatwa al-QaradawiDalamMenanganiIsu-IsuSemasa (Fatwa Method of Al-Qaradawi In Addressing Current Issues), al-Hidayah Publication: Batu Caves, Selangor, Malaysia, 2011.

${ }^{5}$ Ibid. 
In his elaboration of the hadiths, Yusuf al-Qaradawi has also focused on the aspects of the teaching of education, mannerism and morality and about the community. ${ }^{6}$

\section{2) The Book of al-Madkhal li Dirasah al-Sunnah al-Nabawiyyah}

This book is anintroductory or preface to the study of the Sunnah Nabawiyyah. The discussions contained in this book begins with the introduction and importance of the content of the Sunnah, the roles and contributions of the Muslim community towards the preservation of the Sunnah, its position as well as the obligations and methods in interacting with the Sunnah, the principles and the conditions in understanding the content of the Sunnah. In discussing the content of this religious book, Yusuf al-Qaradawi touches on some of the methods related to the Sunnah which exhibit or demonstrate the wasatiyyah characteristics as highlighted by him in understanding the content of the Sunnah. Several of the methods are; the Sunnah that are characterized by the balanced method (mutawazin), and the easy method (muyassar). Both methods have already demonstrated the wasatiyyah characteristics to be introduced by Yusuf alQaradawi in relation to the content of the Sunnah. ${ }^{7}$

\section{3) The Book of KayfaNata 'amalMa'a al-Sunnah al-Nabawiyyah ${ }^{8}$}

The content of this book is the same as the content of the discussion in the book al-Madkhal li Dirasah al-Sunnah alNabawiyyah. However, some slight differences and additions have been made by al-Qaradawi in several sub-topics of the discussion in the introductory chapter of both books, as well as in the second chapter of the book KayfaNata amalMa`a al-Sunnah al-Nabawiyyah. In the introductory chapter of the book al-Madkhal li Dirasah alSunnah al-Nabawiyyah, al-Qaradawi debates about the introduction to the sunnah, its significance as well as the contributions highlighted by the Muslim community in safeguarding the position of the sunnah. The discussion of the introductory chapter of the book of KayfaNata amalMa'a al-Sunnah al-Nabawiyyah on the other hand, places great emphasis on the issues raised regarding the principles and conditions in understanding the sunnah, the role of the sunnah in dealing with problems of the society, the textual and contextual understanding of the sunnah, as well as the reminder about the dangers of the wrong understanding or interpretation of the sunnah.

\section{4) The Book of al-Sunnah Masdaran li al-Ma'rifahwa al-Hadarah'}

This book was written by al-Qaradawi in discussing the role of the Sunnah in the development of mankind's intellect and civilization. There are three major topics in the discussion of this book as presented by al-Qaradawi. The first topic discusses the role of the sunnah as a source in the Islamic religious law. The second topic deals with the issue of the sunnah as a source of knowledge and understanding (intellectual development). The third topic is related to the sunnah as a source of development and civilisation of mankind. The discussion in the first topic also touches on the division of the sunnah based on the category of sunnah which have been tasyri (become the law of Shari'a) and not tasyri' (the special Sunnah (khususiyyah) to the Prophet Muhammadp.b.u.h). Al-Qaradawi has also presented a discussion of this first topic regarding a hadith that is often misused, leading to the implication of the Muslims abandoning the sunnah and hadiths of the Prophet Muhammad PBUH. The hadith was stated by the Prophet regarding the global affairs that are more understood by His people and thus they are more knowledgeable in dealing with and handling the affairs. According to al-Qaradawi, this hadith has also been misused by the enemies of Islam through their wrong interpretation of the hadith with the intention of damaging the faith or belief of the Muslim community towards the sunnah and hadiths of the Prophet Muhammad PBUH. ${ }^{10}$

\section{5) The Book of Al-Sunnah waMuwajahahHamalat al-Tasykik ${ }^{11}$}

\footnotetext{
${ }^{6}$ Al-Qaradawi, Fi Rihab al-Sunnah SyarhAhadith al-Nabawiyyah(Explanation of The Prophetic Hadiths) MaktabahWahbah, Cairo, 2010.

${ }^{7}$ Al-Qaradawi,al-Madkhal Li Dirasah al-Sunnah al-Nabawiyyah(Introduction to the study of the Prophetic Sunnah), cet. ke 5, MaktabahWahbah, Cairo, 2004.

${ }^{8}$ Al-Qaradawi,KayfaNata`amalMa`a al-Sunnah al-Nabawiyyah :Ma`alimwaDawabit(How To Interact With Prophetic Sunnah), cet. ke 2, Virginia, al-Ma`ahad al-`Alami li al-Fikr al-Islami, 1990.

${ }^{9}$ Al-Qaradawi, Al-Sunnah masdaran li al-ma'rifahwa al-Hadharah(al-Sunnah IsA Source of Knowledge and Civilization), Dar al-Syuruq, Beirut, Lebanon, 1998.

${ }^{10}$ Ibid.

${ }^{11}$ Al-Qaradawi,Al-Sunnah waMuwajahahHamalat al-Tasykik, (Al-Sunnah and Face Campaigns of Skepticism),MaktabahWahbah, Cairo, 2011.
} 
This book was written by al-Qaradawi in defending the sunnah from the groups that try to create misperceptions towards the sunnah institution. He presents the views and the actions of the enemies of Islam in the effort of triggering the consciousness among the Muslims in defending the sunnah institution from the threats of the enemies. Al-Qaradawi mentionsthat the Muslims are now veiled by weakness and ignorance which lead to their inability to confront the attacks from these enemies. The mental handcuffs done by the enemies of Islam in creating doubts among the Muslims focuses more on the sunnah institution compared to the Holy Quran. Furthermore, according to al-Qaradawi, the attacks in bringing down this second source of the Islamic religious law are not new but have taken place much earlier. At present, the efforts and attacks are continued by the orientalists and those who are influenced by the arguments of these groups, who are among the Muslims themselves and are yet ignorant of their position and responsibility in defending the sunnah institution. Therefore, al-Qaradawi through this work aims to bring about awareness in the Muslim community of the reality faced by the sunnah institution, apart from creating a proactive effort in defending this institution through the recommendations and efforts presented by him in this piece of writing.

\section{6) The Book of NahwMawsu'ah Li al-Hadith al-Sahih : Masyru'ManhajMuqtarah' ${ }^{12}$}

This is a book written by Yusuf al-Qaradawi in presenting the proposed development of the "Encyclopedia of Authentic Hadiths" project. This book was produced in response to the resolution of the Third International Seminar on Sirah and Sunnah al-Nabawiyyah, which was held in Doha, Qatar in 1401H. One of the resolutions presented in this seminar was the proposal for the establishment of the Centre for the Study of Sirah and Sunnah al-Nabawiyyah, as well as the creation of the Encyclopedia of Nabawiyyah Hadiths. This encyclopedia contains authentic hadiths (sahih hadiths) that have been thoroughly and accurately examined (tahqiq), placed in chapters and arranged in a good order, as well as containing lessons that relate to the current situation. This encyclopedia is not specified for those who are engaged in the field of hadiths alone but also for the use of all parties, to be referred to by the Muslim intellectuals living in this era. Yusuf al-Qaradawi presented the recommendation to produce this encyclopedia from the aspect of the arrangement of the chapters, the selection of the hadiths specified to authentic, sound hadiths (sahih) and strong, good hadiths (hasan) only, which function as the benchmark in distinguishing between accepted and rejected hadiths.

\section{The Basic Principles in Interacting with the Sunnah According to al-Qaradawi}

In his writings, al-Qaradawi places great emphasis on the methods and principles in interacting with the Quran and the Sunnah to avoid misunderstanding of the two sources of syari'a. In interacting with the sunnah, al-Qaradawi presents several basic principles and methods as the following ${ }^{13}$ :

i. To ensure the validity of the hadiths received based on the detailed study of the hadithsand based on the views of the great scholars of hadith.

ii. To understand both the textual and contextual evidence or arguments (nas) of the hadiths, to know the specific causes or reasons behind the revelation of the hadiths (Asbabwurud), as well as based on the understanding of the evidence or arguments (nas) of the Quranic verses and the related hadiths. The hadiths also need to be viewed from the perspective of the general principles as well as the maqasidsyara which is more comprehensive in nature to distinguish between the sunnah that are tasyri I and those that are not tasyri $i$.

iii. To ensure that the revealed evidence or arguments (nas) do not contradict other nas of higher level of credibility, such as the nas from the Quran or other hadiths that are clearly more valid compared to the existing one. The same goes for other nas that are more parallel in their understanding with the understanding of the syara', or those that confirm more to the general maqasidsyara ' that are definitive (qat $i$ i) in nature and attain the level of certainty (yaqin). ${ }^{14}$

\footnotetext{
${ }^{12}$ Al-Qaradawi, NahwMawsu'ah li al-Hadith al-Sahih(Towards An Encyclopedia Of The Hadith Sahih: Proposed Curriculum Project), MaktabahWahbah: Cairo, 2002.

${ }^{13}$ Al-Qaradawi,al-Madkhal Li Dirasah al-Sunnah al-Nabawiyyah(Introduction to the study of the Prophetic Sunnah), MaktabahWahbah, Cairo, 2004, page 99.

${ }^{14}$ Al-Qaradawi,al-Madkhal Li Dirasah al-Sunnah al-Nabawiyyah(Introduction to the study of the Prophetic Sunnah), MaktabahWahbah, Cairo, 2004, page 100. 
These are the three basic principles proposed by al-Qaradawi in interacting with a hadith, and before making the hadith as an argument (hujjah) and as proof or evidence (dalil) against an issue. These three proposed principles contain two main points on the basis of an interaction, namely: the selection and filtration of a hadith from the aspect of its acceptance and rejection (من حيث القبول والرد), as well as the fiqh and deep understanding of the hadith. However, from the perspective of figh and the understanding of hadiths, there are specific conditions and principles that have been detailed by al-Qaradawi, and the author will present those terms and principles in the following discussion of the topic, which is; Fiqh al-Hadith According to al-Qaradawi.

\section{Fiqh al-Hadith According to al-Qaradawi}

Having presented the general principles in interacting with the sunnah, al-Qaradawi has also presented several conditions and principles in determining the fiqh al-hadith so that the understanding that is formed of the hadithsare being isolated, are preserved from the misguided understanding. In his book al-Madkhal li Dirasah al-Sunnah alNabawiyyah, al-Qaradawi proposes six principles and conditions in understanding a hadith. The six conditions are as follows:

i. To understand the Sunnah from the perspective of the Quran.

ii. To search for and gather hadiths under the same topic of discussion.

iii. To unify (al-Jam') or to give preference or priority (tarjih) over the disputed hadiths.

iv. To understand the hadiths by referring to sababwurud al-hadith, which is the understanding of the context and the maqasid contained in the hadiths.

v. To distinguish between the means (wasilah) which fluctuates with fixed goals (hadaf) in a hadith.

vi. To distinguish between facts and metaphorical matters (majaz)in understanding a hadith.

\section{The Discussion of Several Issues in Relation to al-Qaradawi's Concept of al-Wasatiyyah: A Study on the Presented Hadiths}

The discussion of al-Qaradawi's concept of al-wasatiyyah is based on the selection of several hadiths which he has quoted regarding the issues of faith, worship, community, the economy, education and health. The content of the discussion is quoted from his writings on the hadiths which focus on the issues discussed directly. Besides that, the author has also quoted many of the facts of the discussion from al-Qaradawi's writing of FatawaMu'asirah since this piece discusses a lot on the main issues being argued, apart from its ability to prove al-Qaradawi's views of the alwasatiyyah concept based on the quotation of the fatwa and the proofs or evidence (dalil) of the hadiths presented by him.

\section{Al-Qaradawi'sal-Wasatiyyah Regarding the Issue of Faith (Aqidah)}

Al-Qaradawi has presented numerous hadiths in his writings in discussing the issue of faith (aqidah). The evidence of the quotations of the hadiths is not only contained in his direct writings of the hadiths but can also be found in his other works in a myriad of titles. This is because, hadithsare the fundamental source in the discussion of major issues in Islam, including the issue of faith. Another main issue related to the issue of faith and is widely presented by alQaradawi is regarding the issue of takfir, which is the declaration of another Muslim as an unbeliever (kafir) made by other Muslims, in the Muslim community. Islam places a person's faith and religious belief as a scale in assessing the position or the depth of his creed in the eyes of Allah. However, a person's faith and belief may lead to his downfall if he practices deeds that contradict the religion, hence causing him to be renounced from Islam. Nonetheless, the attitude in judging and punishing a Muslim as an infidel is not as easy as expressing it verbally. It requires for very strict conditions as well as strong evidence before a person can be claimed as an infidel or has been renounced from the religion. Al-Qaradawi has also commented on this takfir phenomenon which is widespread in the Muslim community. He has quoted several hadiths of the Prophet Muhammad and has presented important methods in dealing with this issue, apart from creating the attitude of al-wasatiyyah in providing better solutions towards the settlement of the issue. Below are some of the hadiths presented by al-Qaradawi regarding the issue of takfir:

The hadith on the preservation or protection of the blood of a person who has uttered the syahadah is presented by alQaradawi in discussing the punishment of a Muslim's infidelity (takfir). According to al-Qaradawi, it is not easy for a Muslim to pronounce the takfir punishment against his fellow Muslim brothers since it involves clear evidence and support in claiming that a person has renegated from Islam. The hadith presented in relation to this matter is as follows: 
"I have been commanded to wage war against mankind until they utter la ilahailla Allah (until they testify that none is to be worshipped but Allah and that Muhammad is His Messenger), and when they do so, their blood and property are reserved or protected from me, unless due to the cause of syara', while the reckoning is (up to) Allah". ${ }^{15}$

The hadith regarding the Prophet Muhammad PBUH repudiating the action of his companion (sahabah), Usamahibni Zaid, who took the action of killing an enemy who had uttered the syahadah. The incident occurred while Usamah was pointing his sword at the enemy during a battle, and the enemy suddenly uttered the syahadah. Usamah had strongly believed (ijtihad) that the enemy had acted in such a way only out of fear of being killed. The Prophet however, repudiated Usamah's action as stated in the following hadith:

This hadith is about Usamah bin Zaid r.a. who had killed a man during a battle. This happened when he pointed the sword to the man and suddenly the man uttered "la ilahailla Allah". Rasulullah PBUHhad totally disagreed with his action. Therefore, Rasulullah PBUH said: "Did you kill him after he had said, "la ilahaillah Allah"? Usamah said:" He said so out of fear of the sword? Rasulullah PBUH then said: "Can you know the contents of his heart"? ${ }^{16}$

This hadith is presented by al-Qaradawi regarding the position of a Muslim once he utters the syahadah. The syahadah is the key for a person in embracing the religion of Islam, hence it is not easy to accuse a person of infidelity. The above hadith clearly shows that the allegations of a person's infidelity is made only based on the outward judgement of his actions. A Muslim cannot be accused of infidelity if his outward actions do not clearly show or reflect his status of infidelity. Based on this hadith, al-Qaradawi has createda general method in this takfir issue whereby a person's verbal testament of the syahadah already categorises him as a Muslim, and he is thus bound by the Islamic laws and regulations. Based on this hadithtoo, al-Qaradawi states that although an individual has secretly renounced the religion in his heart, yet the judgement of his actions is made only outwardly and thus the allegation of infidelity cannot be made against him as long as it is not disclosed openly.

The hadiths that demonstrate that those who did not die in the state of associating others with Allah or in worshiping others than Allah alone (committing syirk), despite having committed great sins will survive from the everlasting punishment in Hell, and still could gain entrance to the Paradise of Allah the Almighty. The hadiths discussed in relation to this matter are as follows :

From Abu Dzarr.a who said: I went to the Messenger of Allah PBUH who then said: "No servant who utters the words of la ilahailla Allah and then die after saying it unless he is placed in paradise". ${ }^{17}$

Another hadith presented by al-Qaradawi regarding this issue is:

"Verily, Allah has forbidden those who utter the words of la ilahailla Allah in the hope of attaining the pleasure of Allah from Hell fire". ${ }^{18}$

The following hadith is also presented by al-Qaradawi in relation to the takfir issue:

Will be removed from hell those who testify to the words la ilahailla Allah and in their hearts contained kindness as heavy as that of a single grain of wheat" $" 19$

The above three hadithsand several other hadiths are presented by al-Qaradawi in debating the methods that could harmonies the approach in handling the issue of takfir. These hadiths could be understood as stating that those who died not in the state of committing syirk to Allah the Almighty still stand the chance of entering heaven, despite having committed great sins.

According to al-Qaradawi, this is one of the methods used in developing a rationale, non-hasty approach in passing judgem-ent about the renouncement of the religion by a Muslim, besides adhering to the methods prescribed by the

\footnotetext{
${ }^{15}$ Hadith of Sahih al-Bukhari, The Book of al-Iman?), Chapter ".if they repent and perform the prayers and give out the zakat (alms), then give them freedom...", hadith number 25.

${ }^{16}$ Hadith of Sahih Muslim, Book of al-Iman, Chapter TahrimQatl al-KafirBa'daQawlihi La IlahaIlla Allah, hadith number 158.

${ }^{17}$ Hadith of Sahih Muslim, Book of al-Iman, Chapter al-Dalil Ala Man Mata La Yusyrik bi Allah Syay 'an Dakhala al-Jannah wa Inna Man Mata MusyrikanDakhala al-Nar, hadith number 154.

${ }^{18}$ Hadith of Sahih al-Bukhari, Book of al-Tahajjud, Chapter Solah al-NawafilJamaah, hadith number 1186.

${ }^{19}$ Hadith of Sahih al-Bukhari, Book of al-Tawhid, hadith number 7410.
} 
Quran and the hadiths regarding this issue. The debate mentioned above is part of the hadiths put forward by alQaradawi regarding the phenomenon of the takfir issue among the Muslim community. Al-Qaradawi has presented the methods as mentioned prescribe in the Quran and the hadiths of the Prophet Muhammad PBUH in addressing this issue properly. This matter according to al-Qaradawi, involves the position of a Muslim person's faith and he must not be easily accused of infidelity. This al-Qaradawi's approach is seen as a more equitable approach of al-wasatiyyah, as well as conforming to the content of the teachings of Islam through the teachings of the Prophet.

\section{Al-Qaradawi's Concept of al-Wasatiyyah in Relation to the Issue of Worship (Ibadah)}

Al-Qaradawi explains the essence of Worship (Ibadah), and also adheres to the concept of al-wasatiyah, in which he gives examples of two extremes in understanding the concept. The first group, claiming to be more noble than the Prophet and the Messenger because of God's love for him and he no longer needs to do good deeds. And the second group claims that there is no concept of love in worship and that it does not conform to the concept of fear in worship. A servant should be obedient and obedient only with fear. As for love, it will deny that fear. The concept of Qaradawi brought about was that a slave was asked to worship Allah by always practicing good deeds with the fear of not being accepted and being enraged by Allah, and hoping to be accepted and thus receiving His pleasure and the reward of Heaven. At the same time the love will present the sweetness of faith promised in the Hadith. And the sweetness of the faith is not obtained except in the love of God and His Messenger as recorded in the hadiths ${ }^{20}$. Al-Qaradawi has also presented a great deal of views on the issue of worship (ibadah), as well as the hadiths used as the proof or the evidence (dalil) in supporting his views on this issue. The principle of al-wasatiyyah is still used by al-Qaradawi when presenting his views regarding this issue. This is evident through his views which are seen to facilitate the society's practice of the worship (ibadah) by moving away from extreme or exaggerated views. The author therefore presents three examples of al-Qaradawi's views on the issues related to the aspect of worship (ibadah) by using the evidence (dalil) from the hadiths as the guideline as presented by al-Qaradawi.

\section{The Lowering or Lengthening of The Hemline While Praying}

The issue of lowering or lengthening the hemline of the garment below the ankle is among the issues that has become a polemic among the Muslims. This is due to the understanding of the hadith which prohibits a man from extending or lowering the hemline of his garment below the ankle while performing solat (praying). The hadith is as follows:

Which means: "Whoever extends or lengthens his garment while praying with the aim of showing off or to be arrogant, Allah does not put him in a halal condition in committing a sin and does not prevent him from doing sinful things". 21

The hadith literally prohibits a person from lengthening or lowering the hemline of his garment while performing the solat. However, according to al-Qaradawi, there is a need to differentiate between a person who does so with the intention of showing it off with another person who does the same merely to conform to the normal practice and customs of the local community of a country, and not with the intention of showing off. According to al-Qaradawi, this situation is clear through several other hadiths which discuss the same topic. The reference made to the views of hadith scholars who defined and elaborated on the topic has facilitated the clear understanding of the actual threat contained in the hadith. Al-Qaradawi summarises the views of the hadith scholars, among them Imam al-Nawawi and Ibn Hajar alAsqalani, who state that the solat of a person who wears his garment below the ankle is harus, which is permissible by the religion and a person is not sinful for doing it or abandoning it, if it is done on the basis of merely conforming to the customary practices of the local community, and the person is therefore excluded from the threats contained in the hadith. This discussion is based on the understanding of several other hadiths put forward by al-Qaradawi under the same topic of discussion. Among the hadiths are those which state that Allah the Almighty will not look upon those who lengthen or lower the hemline of their garments on the Day of Judgement only if it is done with the intention of showing it off, with the overall meaning of the specified hadith as follows :

"Whoever draws (lowers) his garment with the intention of showing off, Allah will not look at him on the Day of Judgment. Abu Bakr said: One part of my garment trails to the ground, but I will always lift it. Then the Prophet Muhammad PBUH said, "What you do is not with the intention of showing off".

\footnotetext{
${ }^{20}$ Al-Qaradawi, al-Ibadat fil Islam, 36-43, cet. ke 24, MaktabahWahbah, Cairo, 2004.

${ }^{21}$ Hadith of Sunan Abi Daud, Book of al-Solah, Chapter al-Isbal fi al-Solah, hadith number 637.

${ }^{22}$ Hadith of Sahih al-Bukhari, Book of al-Libas, Chapter Man JarraIzarahu Min Ghayr Khuyala', hadith number 5784.
} 
Al-Qaradawi presents this hadith as one of the proof or evidence (dalil) regarding the threat to those who lengthen or lower their garments is taqyid, which is specifically reserved or restricted, only for those whose intention is to show off. This hadith also shows that it is neither prohibited, nor is it recommended (harus/mubah) for a person to lengthen or lower his garment below the ankle if it is done on the basis of conforming to the customary practices of the community and is therefore excluded from the threat mentioned in the hadith. Al-Qaradawi further adds that the issues of clothing, the manners in donning them and their designs are bound by the culture and the customary practices (uruf) of the given society, which are different based on the type of weather, economic status, type of career, living standards and so on. Syarak has thus provided some slack and ease in this matter, except within a certain limit for preventing wastage, the display of luxury or arrogance in wearing a certain piece of garment. ${ }^{\mathrm{i}}$ This is what the abstentions and prohibitions of the syarak with regard to the wearing of clothes in the life of a Muslim actually means.

\section{Fasting While Travelling}

Al-Qaradawi has also debated on the issue of fasting while travelling in the month of Ramadhan. Scholars differ in their views regarding this issue. Some scholars recommend for people to fast while travelling, while others believe one should not continue fasting while travelling. Al-Qaradawi believes the priority is for a person to discontinue fasting while travelling. This is because fasting while travelling may cause difficulties, and fasting is even prohibited if it causes a person to become tired and lethargic. This argument is presented through the following hadith:

It is reported from Jabir bin Abd Allah r.a who said that the Prophet Muhammad PBUH saw a man stationed in a shady place - after falling due to fatigue - and the crowds were surrounding him, then the Prophet SAW said, "Fasting while travelling is not considered as an act of welfare". ${ }^{23}$

Al-Qaradawi presents the dalil of this hadith when issuing the fatwa that the preference for a person who is travelling is to break his fast (to discontinue fasting), with the argument that people who are travelling often go through numerous difficulties and obstacles. With reference to the elaboration made by the religious scholars on this hadith, the man was placed under the shade due to fatigue caused by fasting, and the statement of the Prophet Muhammad PBUH that categorizes the fast of a traveller as a non-welfare is bound by a reason. However, in situations where difficulties do not arise, al-Qaradawi therefore prefers the view which facilitates the public in choosing either to fast or not. According to Basri Ibrahim, the preference of al-Qaradawi in situations such as this is to offset matters that make it easier for the community. If it is easier for the society to discontinue fasting, they are then recommended to do so. On the other hand, people who find it easy and are capable of fasting, it is then not sinful for them to continue with this act of worship (ibadah). This approach is also as the evidence (dalil) of the hadith presented by al-Qaradawi, which was narrated by Hamzah bin Amir al-Aslamir.a who said to the Prophet Muhammad p.b.u.h which means:

"O Messenger of Allah, I have the strength to fast in the journey. Is it wrong for me not to fast? To this, the Prophet Muhammad PBUH replied, "To discontinue fasting when travelling is a leniency that Allah has given you. Whoever chooses it is good, and whoever wishes to continue fasting is not a fault for him, 24

Based on this hadith, al-Qaradawi has taken the middle approach and presents a more balanced stand on the matter of fasting while travelling. However, in situations where fasting is difficult or when a person is in pain or illness, alQaradawi is firmer with his view which is to issue the ruling (fatwa) that it is prohibited for such a person to fast based on the first hadith. In situations where a person is in good health and does not face any difficulty in fasting, the person is then given the option to either continue fasting or to break his fast. Nonetheless, it is understood that the view of alQaradawi is the preference for the traveler to discontinue fasting as presented in the second hadith.

\section{Stoning of the Pillars (Jamrah) Before Noon}

Al-Qaradawi has also presented his views regarding the pilgrimage where the application of the al-wasatiyyah concept also needs to be considered. One of the issues disputed by the religious scholars is related to the time of stoning of the pillars (jamrah) done before noon on the days of Tasyriq other than the day of Nahr (10th Zulhijjah). The view that has

\footnotetext{
${ }^{23}$ Hadith of Sunan Abi Daud, Book of al-Siyam, Chapter Ikhtiyar al-Fitr, hadith number 2407.

${ }^{24}$ Hadith of Sahih Muslim, Book of al-Siyam, Chapter al-Takhyir fi al-Sawmwa al-Fitr fi al-Safar, hadith number 107. 
been practiced all this while is that the time for the stoning of the pillars on the days of Tasyriq is between noon and sunset. This argument is based on the authentic hadith narrated by Bukhari as follows:

The Meaning of the Hadith: From Wabarah who said: I asked Ibn Umar r.a: when is the time for me to perform the stoning of the pillars? Ibn Umar said: "When your leader performs the stoning, then you do it", then I repeated the question and Ibn Umar said, "We watch the time, we perform the stoning of the pillars after it is noon". ${ }^{25}$

In this matter, al-Qaradawi considers the benefits of the pilgrims who increase in number each year which causes for the implementation of this ritual to be difficult if there is no leniency in the view of the ritual to be performed only after it is noon. Furthermore, accidents that took place during the stoning of the pillars ritual which led to the death of the pilgrims further support the need for the concept of al-wasatiyyah to be applied. ${ }^{26}$ Al-Qaradawi believes this matter is open to ijtihad, which is the independent reasoning of the religious scholars, which should be a benefit to the Muslim community from time to time. ${ }^{27}$ According to him, there are many views of the fuqaha, (whoare qualified experts in fiqh or Islamic jurisprudence and Islamic law) which state about the leniency of the time in performing the stoning of the pillars ritual before noon. Al-Qaradawi also think that performing this ritual after it is noon is a non-obligatory matter (sunat) shown by the Prophet Muhammad PBUH and there exists no other evidence or proof (dalil) which prohibits the conduct of the ritual before noon. ${ }^{28}$ Ibn Hajar al-Asqalani also has the opinion that the stoning of the jamrah time stipulated after it is noon on the three days of Tasyriq is a non-obligatory matter as demonstrated by the Prophet Muhammad PBUH, which is also the view of the majority of the religious scholars (jumhurulama). Nevertheless, alQaradawi stresses that the fatwa will change with the changing of time, place and conditions of the society. According to him, the issue of the congestion of the pilgrims during this ritual cannot be solved well except by extending the duration in performing the worship (ibadah). According to al-Qaradawi, the view in the leniency in performing the ritual before noon should be celebrated at this point in time, which is also the views of 'Ata' and Tawus, as well as the view of the Hanafi school of thought. ${ }^{29}$ Although this is not the view of the jumhurulama, yet it conforms to the Islamic principles that advocate the facilitation of a matter, apart from several of the fiqh methods presented by al-Qaradawi in demonstrating his preference of the view which permits for the ritual to be performed before noon in such a situation.

\section{Containment of Extremism Attitude in the Hadith Understanding}

As been suggested, the al-Wasatiyyah approach by al-Qaradhawi is to curb the extremism of Muslims as it does not meet the requirements of Islam itself. This al-Wasatiyyah approach also addresses the demands of interacting with the hadith of Rasulullah PBUH through Fiqh Hadith stated. The principles and approaches in this hadith fiqh are parallel to the hadith scholars approach when understanding the hadith in particular from the aspects of the Hadith Rule. ${ }^{30}$ The Prophet's approach to PBUH also through his propaganda is to combat extreme extremism in interacting with this religion. This is all because of the method that is not in line with the approach of al-wasatiyyah which is organized in the teachings of Islam itself. ${ }^{31}$ Extreme attitudes and extreme actions are not the essence of Islamic teachings themselves. Even Islam comes with a gentle tendency without any element of coercion, promoting soul sacrifice to those who reject or refuse to accept it.

Through the guidance of the Quran as the revelation of Allah and the guidance of the hadith of the Prophet, Muslims are taught and educated with good morals by example and example to the way of life of the Prophet. ${ }^{32}$ The correct Fiqh

\footnotetext{
${ }^{25}$ Hadith of Sunan Abi Daud, Book of al-Manasik, Chapter Fi Ramy al-Jimar, hadith number 1972.

${ }^{26}$ Al-Qaradawi,,FatawaMu 'asirah(Contemporary fatwa Volume 3), Dar al-Qalam, Kuwait, 2001, page 266.

${ }^{27}$ Al-Qaradawi,,FatawaMu 'asirah(Contemporary fatwa Volume 3), Dar al-Qalam, Kuwait, 2001, page 268.

${ }^{28} \mathrm{Al}-\mathrm{Q} a \mathrm{radawi,FatawaMu}$ 'asirah(Contemporary fatwa Volume 3), Dar al-Qalam, Kuwait, 2001, page 269.

${ }^{29}$ Al-Qaradawi,,FatawaMu 'asirah(Contemporary fatwa Volume 3), Dar al-Qalam, Kuwait, 2001, page 269.

${ }^{30}$ Muhammad Abu Layth al-KhayrAbadi, 2005, Ulum al-Hadith AsiluhawaMu'asiruha, Dar al-Syakir, Bangi, Selangor, Malaysia, page 307-383.

${ }^{31}$ Abd al-QawiyMakradTarisy Ahmad al-Qadsi, al-Manhaj al-Nabawi Fi TarsikhQiyam al-WasatiyyahwaMuharabah alGhuluwwa al-Tatarruf, Proceeding $4^{\text {th }}$ International Prophetic Heritage Conference (SWAN 2014), UniversitiSains Islam Malaysia (USIM), Nilai, Negeri Sembilan, Malaysia, 2014, page 254.

${ }^{32}$ Khader Ahmad, Mustaffa Abdullah, SedekAriffin, MohdYakub@ZulkifliMohdYusoff, 2016, Fanatik Beragama Dalam Kalangan Masyarakat Islam Di Malaysia : AnalisisBerdasarkanPemahamanTerhadapFiqh al-Hadith, (Religious Fanatic Among Islamic Community In Malaysia : Analysis Based on Understanding of Fiqh al-Hadith), Proceeding International Conference On Islam In Malay World VI (ICON-IMAD VI), 20-22 September 2016.
} 
al-Hadith as mentioned by al-Qaradhawi seeks not to misuse literal texts so that they can lead to extreme understanding. Hadith Rasulullahs.a.w should be referred to the ulama in understanding the correct text of the hadith so that it can be applied with the appropriate context in solving the problems that arise in society today.

\section{Conclusion}

Based on the discussion presented, al-Qaradhawi has put forward the basis of Islamic-oriented teachings of alWasatiyyah (moderation) in particular in interacting with the hadiths of Rasulullahs.a.w to avoid extreme attitudes in understanding the text of the source of the Shariah. The Fiqh al-Hadith brought by al-Qaradhawi is in line with the principles of knowledge of Hadhrat al-Hadith as found in the discussion of Ulum al-Hadith. In addition, the Fiqh alHadith presented by al-Qaradhawi is a principle and condition for to avoid extremism in understanding the hadiths of the Prophet The examples set out in this article regarding the understanding of the hadith in the issue of faith and worship by al-Qaradawi show the approach of al-isatiyyah and at the same time abolish the extremist attitude in the understanding of the hadiths of Rasulullah PBUH.

\section{References}

Abd al-QawiyMakradTarisy Ahmad al-Qadsi, al-Manhaj al-Nabawi Fi TarsikhQiyam al-WasatiyyahwaMuharabah alGhuluwwa al-Tatarruf, Proceeding $4^{\text {th }}$ International Prophetic Heritage Conference (SWAN 2014), UniversitiSains Islam Malaysia (USIM), Nilai, Negeri Sembilan, Malaysia, 2014, page 254.

Basri Ibrahim, Metode Fatwa al-QaradawiDalamMenanganiIsu-IsuSemasa (Fatwa Method of Al-QaradawiIn Addressing Current Issues), al-Hidayah Publication: Batu Caves, Selangor, Malaysia, 2011, page 75.

Khader Ahmad, Mustaffa Abdullah, SedekAriffin, MohdYakub@ZulkifliMohdYusoff, 2016,

FanatikBeragamaDalamKalanganMasyarakat Islam Di Malaysia : AnalisisBerdasarkanPemahamanTerhadapFiqh alHadith, (Religious Fanatic Among Islamic Community In Malaysia : Analysis Based on Understanding of Fiqh al-Hadith), Proceeding International Conference On Islam In Malay World VI (ICON-IMAD VI), 20-22 September 2016.

Muhammad Kamil Ab Majid, PemikiranKerohanian Yusuf al-Qaradawi : AnalisisSiri Bukunya al-Tariq Ila Allah (Spiritual Thoughts of Yusuf al-Qaradawi: Analysis of the Book Series of the al-Tariq Ila Allah), Thesis PhD, Department of Aqidah and Islamic Thought, Academy of Islamic Studies, Universityof Malaya, Malaysia, 2011, page 62.

Al-Qaradawi, al-Sahwah al-IslamiyyahBayna al-Ikhtilaf al-Masyru 'wa al-Tafarruq al-Madhmum(Islamic Awakening Between Legitimate Difference andDistortion), cet. ke 5, Dar al-Sahwah, Cairo, 1994, page 49.

Al-Qaradawi, Fi Rihab al-Sunnah SyarhAhadith al-Nabawiyyah(Explanation of The Prophetic Hadiths) MaktabahWahbah, Cairo, 2010.

Al-Qaradawi,al-Madkhal Li Dirasah al-Sunnah al-Nabawiyyah(Introduction to the study of the Prophetic Sunnah), cet. ke 5, MaktabahWahbah, Cairo, 2004.

Al-Qaradawi,KayfaNata `amalMa`a al-Sunnah al-Nabawiyyah :Ma`alimwaDawabit(How To Interact With Prophetic Sunnah), cet. ke 2, Virginia, al-Ma`ahad al-`Alami li al-Fikr al-Islami, 1990.

Al-Qaradawi, NahwMawsu'ah li al-Hadith al-Sahih(Towards An Encyclopedia OfThe Hadith Sahih: Proposed Curriculum Project), MaktabahWahbah: Cairo, 2002.

Al-Qaradawi, al-Ibadat fil Islam, 36-43, cet. ke 24, MaktabahWahbah, Cairo, 2004.

Hadith of Sahih al-Bukhari, Book of al-Libas, Chapter Man JarraIzarahu Min Ghayr Khuyala', hadith number 5784. Hadith of Sunan Abi Daud, Book of al-Siyam, Chapter Ikhtiyar al-Fitr, hadith number 2407.

Hadith of Sahih Muslim, Book of al-Siyam, Chapter al-Takhyir fi al-Sawmwa al-Fitr fi al-Safar, hadith number 107.

Ahmad Munawar Ismail, Wan Kamal Mujani, Ahmad AimanZuhaily A.M, Methods of Da'wah and Social Network in Dealing with Liberalism and Extremism, Journal Islamiyyat, vol 40 (2), 2018, 131-139.

Al-Qaradawi,KayfaNata amalMa`a al-Sunnah al-Nabawiyyah :Ma`alimwaDawabit(How To Interact With Prophetic Sunnah), cet. ke 2, Virginia, al-Ma`ahad al-'Alami li al-Fikr al-Islami, 1990. 